\section{REFERENCES}

Ainley, N. J. (1961). f. Obstet. Gynaec. Brit. Cwlth, 68, 254

Ball, E. W., and Giles, C. (1964). ₹. clin. Path., 17, 165.

Berry, V., Booth, M. A., Chanarin, I., and Rothman, D. (1963). Brit. med. F., 2, 1103 .

Chanarin, I., MacGibbon, B. M., O'Sullivan, W. J., and Mollin, D. L. (1959). Lancet, 2, 634 .

Rothman, D., and Watson-Williams, E. J. (1963). Ibid., 1, 1068.

Coyle, C., and Geoghegan, F. (1962). Proc. roy. Soc. Med., 55, 764.

Dacie, J. V. (1958). Practical Haematology. Churchill, London.

Elliott, B. A., Jepson, E. M., and Wilkinson, J. H. (1962). Clin. Sci., 23, 305 .

and Wilkinson, J. H. (1961). Lancet, 1, 698.

- (1963). Clin. Sci., 24, 343.

Forshaw, J. W. B., Jones, A. T., Chisholm, W. N., and McGinley, W. K. (1957). F. Obstet. Gynaec. Brit. Emp., 64, 255.

Francis, H. H., and Scott, J. S. (1959). Lancet, 2, 1033.

Fullerton, W. T., and Turner, A. G. (1962). Ibid., 1, 75.

and Watson-Williams, E. J. (1962). f. Obstet. Gynaec. Brit. Cwlth, 69, 729.

Giblett, E. R., Coleman, D. H., Pirzio-Biroli, G., Donohue, D. M., Motulski, A. G., and Finch, C. A. (1956). Blood, 11, 291.

Giles, C., and Burton, H. (1960). Brit. med. F., 2, 636.

Giles, C., and Shuttleworth, E. M. (1958). Lancet, 2, 1341.
Heller, P., West, M., and Zimmerman, H. J. (1959). Clin. Res., 7, 207.

Herbert, V. (1961). F. clin. Invest., 40, 81

Hess, B., and Gehm, E. (1955). Klin. W schr., 33, 91.

Hibbard, E. D. (1962). F. Obstet. Gynaec. Brit. Cwlth, 69, 739.

Hourihane, B., Coyle, C. V., and Drury, M. I. (1960). F. Irish med. Ass., 47, 1 .

King, E. J., and Campbell, D. M. (1961). Clin. chim. Acta, 6, 301

King, E. J., and Campbell, D. M. (1961). Clin. ch
King, J. (1959). 7. med. Lab. Technol., 16, 265.

Lehmann, H., and Ager, J. A. M. (1961). Association of Clinical Pathologists, Broadsheet No. 33.

Levitan, R., Wasserman, L. R., and Wróblewski, F. (1959). Clin. Res. 7, 217 .

Lowenstein, L., Pick, C., and Philpott, N. (1955). Amer. F. Obstet. Gynec., 70, 1309 .

MacKenzie, A., and Abbott, J. (1960). Brit. med. f., 2, 1114.

Rosalki, S. B.'(1962). F. clin. Path., 15, 566.

Rosalki, S. B. (1962). F. Clin. Path., 15, 566.

Rosenthal, H.' L., and Sarett, H. P. (1952). F. biol. Chem., 199, 433.

Solomons, E., Lee, S. L., Wasserman, M., and Malkin, J. (1962). F. Obstet. Gynaec. Brit. Cwlth, 69, 724.

Wróblewski, F., and LaDue, J. S. (1955). Proc. Soc. exp. Biol. (N.Y.) 90, 210.

Zachau-Christiansen, B., Hoff-Jørgensen, E., and Østergård Kristensen, H. P. (1962). Dan. med. Bull., 9, 157.

\title{
Influence of Sex and ABO Blood Group on the Normal Lymphocyte Transfer Test
}

\author{
J. F. MOORHEAD, ${ }^{*} \dagger$ M.B., M.R.C.P. ; A. R. PATEL,* M.B., CH.M., F.R.C.S.
}

Brit. med. F., 1964, 2, 1111-1113

Considerable interest has recently been shown in the normal lymphocyte-transfer test, first described by Brent and Medawar (1963). They showed that in guinea-pigs a local reaction of varying intensity was produced by the intradermal injection of homologous lymphocytes. This reaction was correlated with the order of rejection of skin grafts when these were made from the lymphocyte recipients to the lymphocyte donor. A similar test was carried out in human beings by Gray and Russell (1963), Bridges et al. (1964), and Goldsmith (1964).

Since the influence of $\mathrm{ABO}$ blood group and sex on the reaction has not been previously reported in humans, an experiment was designed to evaluate these factors. At the same time an opportunity was taken to obtain detailed information about the reaction.

\section{Preparation of Lymphocytes}

Aseptic precautions were observed throughout the procedure. Thirty millilitres of blood was defibrinated at room temperature by gentle shaking in a conical flask containing 12 glass beads. Then $25 \mathrm{ml}$. of $3 \%$ Dextraven in normal saline was added and the suspension allowed to sediment for 30 minutes at $37^{\circ} \mathrm{C}$., so that most of the red cells, neutrophils, and platelets separated out, leaving a high concentration of lymphocytes in the supernatant. The latter was then aspirated into a glass tube and centrifuged for 10 minutes at 1,500 r.p.m. The top layer was discarded from the tube except for approximately $1.5 \mathrm{ml}$., which was used to re-suspend the deposited cells. These were allowed to sediment at $37^{\circ} \mathrm{C}$. for 45 minutes in order to remove more of the contaminating red cells, and the final supernatant containing a high concentration of lymphocytes was placed in a glass container. The number of lymphocytes

* From the Nuffield Unit of Medical Genetics in the Department of Medicine, University of Liverpool, and the Artificial Kidney Unit, Sefton General Hospital, Liverpool.

+ Now at Renal and Electrolyte Division, Georgetown University Hospital, Washington, D.C. obtained in this way varied from $10 \times 10^{6}$ to $50 \times 10^{6}$ per ml. in a total volume of approximately $1-1.5 \mathrm{ml}$. The final preparation was contaminated with red cells to the extent of 50 to $75 \%$ of the number of lymphocytes. Few neutrophils and platelets remained. This preparation was tested each time for bacteriological sterility, and no organisms were cultured from any preparation. The lymphocyte viability was tested with trypan blue ; the number of dead cells was never more than $1 \%$.

Tests done at the National Institute for Medical Research demonstrated that $3 \%$ dextran in normal saline was completely non-toxic to lymphocytes.

\section{Experiment}

Twenty-four accredited blood donors (volunteers) were used, 12 of each sex. In order to avoid the possible dangers of $\mathrm{Rh}$ sensitization (because a few red cells are inevitably injected), all the women volunteers were post-menopausal. The men were in the age-group 45-55 years.

The design, purpose, and possible dangers of the experiment were fully explained to every volunteer on at least two occasions. Four of the 24 volunteers (two men and two women) donated lymphocytes; the remaining 20 each received one lymphocyte dose from all four donors. The recipients were all group A, $\mathrm{Rh}$-positive, while the donors consisted of two males-one $\mathrm{A}$, $\mathrm{Rh}$-positive, and the other B, Rh-positive-and two femalesone A, Rh-positive, and the other B, Rh-positive. Some of the other minor blood groups were also determined, and these are recorded in Table $\mathrm{I}$.

It had been found in the pilot experiments (see below), using different body sites, that the upper part of the flexor aspect of the forearm was the most suitable for reading results, and this area was therefore chosen for subsequent tests. The sites were numbered 1 to 4 from right to left, there being two sites on each arm. In order to eliminate as far as possible the 
influence of site on reaction, the suspensions were numbered 1 to 4 and selected randomly; the sites were used in the same order (1 to 4) for each patient. The donors, each received an injection of their own cells, which in no case produced a response.

\begin{tabular}{|c|c|c|c|c|c|c|c|c|c|}
\hline Sex & No. & $\mathrm{ABO}$ & $\begin{array}{l}\text { Probable } \\
\text { Rh } \\
\text { Genotype }\end{array}$ & $M N$ & $\mathrm{~s}$ & $\mathbf{P}$ & Kell & $\mathrm{Fy}^{\mathrm{B}}$ & Le \\
\hline \multicolumn{10}{|c|}{ Donors of Lymphocytes } \\
\hline $\begin{array}{l}\text { Male } \\
\text { Female } \\
\text { Male } \\
\text { Female }\end{array}$ & $\begin{array}{l}1 \\
2 \\
3 \\
4\end{array}$ & $\begin{array}{l}\mathrm{A}_{1} \\
\mathrm{~A}_{1} \\
\mathrm{~B} \\
\mathrm{~B}\end{array}$ & $\begin{array}{l}\mathrm{cDE} / \mathrm{cde} \\
\mathrm{CDe} / \mathrm{cde} \\
\mathrm{cDE} / \mathrm{cDE} \\
\mathrm{CDe} / \mathrm{cde}\end{array}$ & $\begin{array}{l}\mathrm{N} \\
M N \\
M N \\
M N\end{array}$ & $\begin{array}{l}\overline{-} \\
\bar{t} \\
+\end{array}$ & $\begin{array}{l}+ \\
+ \\
+ \\
-\end{array}$ & $\begin{array}{l}\bar{z} \\
\bar{z}\end{array}$ & $\begin{array}{l}+ \\
+ \\
+\end{array}$ & $\begin{array}{l}\mathrm{Le}^{\mathrm{b}} \\
\mathrm{Le}^{\mathrm{b}} \\
=\end{array}$ \\
\hline \multirow{2}{*}{\multicolumn{10}{|c|}{ Recipients of Lymphocytes }} \\
\hline Male & & & & & & & & & \\
\hline Male & 1 & $A_{1}$ & CDe/cde & $M$ & + & - & - & - & - \\
\hline " & $\begin{array}{l}2 \\
3\end{array}$ & $\begin{array}{l}A_{1} \\
A_{1}\end{array}$ & $\begin{array}{l}\text { CDe/CDe } \\
\text { CDe/cde }\end{array}$ & $\begin{array}{l}M N \\
M N\end{array}$ & \pm & $\stackrel{+}{+}$ & \pm & \pm & $\bar{L} e^{b}$ \\
\hline ", & 4 & $\begin{array}{ll}A_{1} \\
A_{2}\end{array}$ & $\mathrm{CDe} / \mathrm{cDe}$ & $M N$ & + & - & - & - & $\mathrm{Le}^{\mathrm{s}}$ \\
\hline " & 5 & $A_{1}$ & CDe/cde & $M N$ & - & + & - & + & $\bar{L} e^{b}$ \\
\hline ", & 6 & $A_{1}$ & $\begin{array}{l}\text { CDe/cde } \\
\text { CDelCDe }\end{array}$ & $M N$ & $\bar{t}$ & \pm & 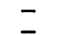 & I & $\mathrm{Le}^{\mathrm{b}}$ \\
\hline " & 7 & $\mathrm{~A}_{2}$ & CDe/CDe & $M N$ & + & + & - & + & $\mathrm{Le}^{\mathrm{a}}$ \\
\hline פט & $\begin{array}{l}8 \\
9\end{array}$ & $\begin{array}{l}A_{2} \\
A_{1}\end{array}$ & $\begin{array}{l}\text { cDE/cde } \\
\mathrm{CDe} / \mathrm{CDe}\end{array}$ & $M$ & $\begin{array}{llll}+ \\
+\end{array}$ & $\begin{array}{l}+ \\
+\end{array}$ & $=$ & $\begin{array}{llll}+ \\
+\end{array}$ & $\begin{array}{l}\mathrm{Le}^{\mathrm{b}} \\
\mathrm{Le}^{\mathrm{s}}\end{array}$ \\
\hline ," & 10 & $\mathrm{~A}_{1}$ & $\mathrm{cDe} / \mathrm{cde}$ & $M N$ & $\begin{array}{l}t \\
+\end{array}$ & + & + & t & $\mathrm{Le}^{\mathrm{b}}$ \\
\hline Female & 1 & $\mathrm{~A}_{2}$ & $\mathrm{CDe} / \mathrm{CDe}$ & $M N$ & + & + & - & - & - \\
\hline ", & 2 & $\mathrm{~A}_{1}$ & CDc/cde & $M$ & + & - & 戸 & \pm & $\mathrm{Le}_{\mathrm{a}}^{\mathrm{a}}$ \\
\hline , & 3 & $A_{1}$ & cDE/cde & $M N$ & + & \pm & \pm & $\bar{z}$ & $\mathrm{Le}^{\mathrm{b}}$ \\
\hline " & $\begin{array}{l}4 \\
5\end{array}$ & $A_{1}$ & $\begin{array}{l}\text { CDe/cde } \\
\text { CDelde }\end{array}$ & $\mathrm{MN}$ & \pm & $\overline{-}$ & $\bar{z}+$ & \pm & $\overline{-}$ \\
\hline$"$ & $\begin{array}{l}5 \\
6\end{array}$ & $\begin{array}{l}A_{1} \\
A_{1}\end{array}$ & $\begin{array}{l}\text { CDe/cde } \\
\text { cDe/cde }\end{array}$ & $M N$ & $\bar{t}$ & $\bar{t}$ & $\bar{z}$ & $\overline{+}$ & $\mathrm{Le}^{\mathrm{b}}$ \\
\hline ", & 7 & $\begin{array}{l}\mathrm{A}_{1} \\
\mathrm{~A}_{1}\end{array}$ & $\mathrm{CDe} / \mathrm{cDE}$ & $M$ & + & + & - & - & $\overline{\mathrm{L}} \mathrm{e}^{\mathbf{a}}$ \\
\hline 30 & 8 & $A_{1}$ & CDe/cDE & $M N$ & \pm & I & $\bar{z}$ & + & $\mathrm{Le}^{\mathrm{b}}$ \\
\hline ” & $\begin{array}{r}9 \\
10\end{array}$ & $\begin{array}{l}A_{1} \\
A_{2}\end{array}$ & $\begin{array}{l}\text { CDc/CDc } \\
\mathrm{CDe} / \mathrm{CD}\end{array}$ & $\stackrel{M}{M N}$ & $\stackrel{+}{-}$ & $\stackrel{+}{+}$ & $\bar{z}$ & $\begin{array}{l}+ \\
+\end{array}$ & $\overline{\mathrm{Le}^{\mathrm{b}}}$ \\
\hline & & & & & & & & & \\
\hline
\end{tabular}

On the 1st, 2nd, 4th, and 11th day after the injections the areas of the reactions were recorded by outlining them with a ball-point pen and transferring this outline to $1-\mathrm{mm}$. square graph paper. The transfer was effected by pressing a small square of Sellotape over the inked outline; on removing the Sellotape an impression of the outline remained on the adhesive side, so that when this was stuck on to graph paper the

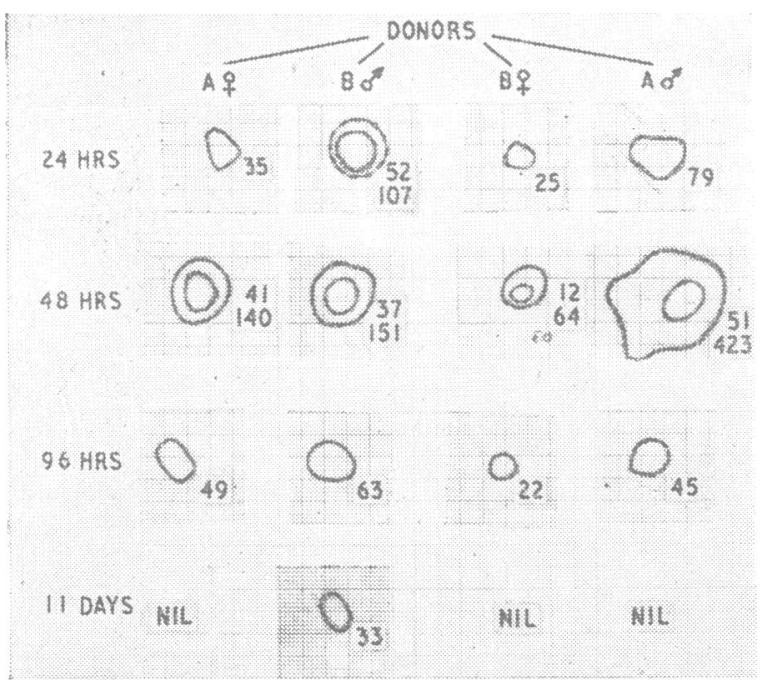

Sellotape outlines and areas in recipient (male 1), blood group A. Inner rings represent a weal within an area of erythema.

number of squares within the outline could easily be counted. The record of the area is thus permanent. The Diagram shows the reactions in one of the 20 recipients.

\section{Results}

Before embarking on the main experiment a number of pilot experiments on human volunteer patients had been performed. In these a variable response was observed. As expected, injection of autologous lymphocytes did not cause a reaction, nor did injections of isologous lymphocytes in one set of identical twins. In one patient with carcinoma of the bronchus who was being treated with corticosteroids and antimetabolites no response occurred to a cell dose of $4.3 \times 10^{6}$ from an unrelated donor. In other patients in the pilot survey and in the main experiment homologous lymphocytes produced a double response. The first reaction appeared after 12 hours; it was read at 24 hours, when erythematous and clearly demarcated from the surrounding skin. At 48 hours the reaction was more intense and in some cases there was a central weal. This reaction faded and had often disappeared by the fifth day, although it sometimes persisted and merged with the second reaction which appeared at the same site on the seventh or eighth day. This had the same macroscopic appearances as the first, but the size was often different. Hardness was difficult to estimate and was therefore ignored.

In the main experiment, although readings of reactions were taken at 24, 48, and 96 hours and at 11 days after injection, the 48-hour response is used in the tables to represent the first reaction. The figures in Table II represent the area of the whole erythematous reaction in square millimetres. Except in one case, no untoward reactions occurred in cell recipients. This volunteer (female, No. 10) developed a generalized urticarial rash one hour after the intradermal injection, and collapsed, but recovered after 24 hours' treatment.

It was suspected that this reaction had resulted from sensitivity to dextran, although so far as is known she had never been previously sensitized. However, such reactions are not uncommon after the administration of dextran preparations to humans (Kabat et al., 1957). Circulating antibody to dextran was not demonstrated, but, using the double-layer leucocyteagglutination technique of Ridges and Augustin (1964), antidextran antibody was found on the patient's leucocytes, but not in her serum, three months after injection of the leucocyte suspensions. Further work is in progress to find out how often such dextran antibodies are present in apparently normal people.

The principal findings in the 20 recipients were as follows:

1. There was no significant effect of the $A B O$ and other red-cell antigens. Thus lymphocytes from A Rh-positive donors when injected into $20 \mathrm{~A} \mathrm{Rh}$-positive recipients produced 32 positive first reactions, whereas in the same recipients cells from the $B \mathrm{Rh}$ positive donors produced only 22 positive first reactions (Table II). $\mathrm{Had}$ a difference in $\mathrm{ABO}$ antigens influenced the reaction the figures might have been expected to be reversed. Nor did the minor blood groups recorded appear to affect the reaction.

2. The sex of the donor and recipient did not detectably influence the first or second reaction (Table II). A more sensitive way of looking at this is in Table III in which the concordance and discordance between donor and recipient for both sex and ABO blood

TABLE II.-Areas of Skin Reactions in sq. $\mathrm{mm}$.

\begin{tabular}{|c|c|c|c|c|c|c|c|c|c|c|c|}
\hline \multicolumn{4}{|c|}{ Cell Recipients } & \multicolumn{8}{|c|}{ Cell Donors } \\
\hline \multirow{2}{*}{\multicolumn{3}{|c|}{ Sex }} & \multirow{2}{*}{ No. } & \multicolumn{2}{|c|}{$\mathrm{A}_{0}{ }^{\circ}$} & \multicolumn{2}{|c|}{ Aㅇ } & \multicolumn{2}{|c|}{$\mathbf{B}_{\hat{\sigma}}^{*}$} & \multicolumn{2}{|c|}{ B? } \\
\hline & & & & 1st & 2nd & 1st & 2nd & 1st & 2nd & 1st & 2nd \\
\hline 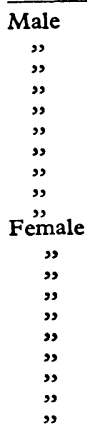 & $\begin{array}{l}\because \\
\because \\
\because \\
\because \\
\because \\
\because \\
\because \\
\because \\
\because \\
\because \\
\because \\
\because\end{array}$ & $\begin{array}{l}\because \\
\because \\
\because \\
\because \\
\because\end{array}$ & $\begin{array}{r}1 \\
2 \\
3 \\
4 \\
5 \\
6 \\
7 \\
8 \\
9 \\
10 \\
1 \\
2 \\
3 \\
4 \\
5 \\
6 \\
7 \\
8 \\
9 \\
10\end{array}$ & $\begin{array}{r}423 \\
12 \\
98 \\
34 \\
130 \\
116 \\
42 \\
22 \\
0 \\
29 \\
50 \\
11 \\
6 \\
0 \\
26 \\
26 \\
184 \\
64 \\
0 \\
18\end{array}$ & $\begin{array}{r}0 \\
40 \\
46 \\
38 \\
24 \\
34 \\
0 \\
14 \\
21 \\
325 \\
52 \\
21 \\
14 \\
0 \\
25 \\
59 \\
34 \\
22 \\
0 \\
188\end{array}$ & $\begin{array}{r}140 \\
40 \\
8 \\
0 \\
240 \\
125 \\
0 \\
0 \\
32 \\
32 \\
0 \\
0 \\
90 \\
38 \\
0 \\
75 \\
14 \\
18 \\
32 \\
30 \\
14\end{array}$ & $\begin{array}{r}0 \\
22 \\
14 \\
0 \\
34 \\
17 \\
0 \\
14 \\
0 \\
0 \\
143 \\
0 \\
28 \\
22 \\
0 \\
13 \\
22 \\
11 \\
19 \\
0 \\
27\end{array}$ & \begin{tabular}{|r|}
151 \\
0 \\
48 \\
0 \\
150 \\
17 \\
0 \\
31 \\
28 \\
0 \\
0 \\
9 \\
9 \\
0 \\
0 \\
140 \\
6 \\
67 \\
46 \\
32
\end{tabular} & $\begin{array}{r}26 \\
20 \\
24 \\
31 \\
25 \\
45 \\
0 \\
13 \\
0 \\
120 \\
0 \\
23 \\
23 \\
0 \\
18 \\
56 \\
15 \\
17 \\
0 \\
30\end{array}$ & $\begin{array}{r}64 \\
0 \\
25 \\
0 \\
52 \\
6 \\
0 \\
0 \\
0 \\
0 \\
0 \\
56 \\
0 \\
25 \\
0 \\
25 \\
0 \\
6 \\
24 \\
0 \\
0\end{array}$ & $\begin{array}{r}0 \\
25 \\
7 \\
21 \\
24 \\
28 \\
0 \\
0 \\
0 \\
205 \\
15 \\
48 \\
9 \\
0 \\
59 \\
0 \\
12 \\
24 \\
0 \\
66\end{array}$ \\
\hline \multicolumn{4}{|c|}{$\begin{array}{l}\text { No. of lymphocytes per ml. } \\
\text { Volume of suspension injected } \\
\text { Approx. No. of lymphocytes } \\
\text { injected }\end{array}$} & \multicolumn{2}{|c|}{$\begin{array}{l}15.5 \times 10^{6} \\
0.15 \mathrm{ml} \\
2.3 \times 10^{6}\end{array}$} & \multicolumn{2}{|c|}{$\begin{array}{l}16.0 \times 10^{6} \\
0.15 \mathrm{ml} \\
2.4 \times 10^{6}\end{array}$} & \multicolumn{2}{|c|}{$\begin{array}{l}17.0 \times 10^{8} \\
0.15 \mathrm{ml} \\
2.5 \times 10^{6}\end{array}$} & \multicolumn{2}{|c|}{$\begin{array}{l}11.5 \times 10^{8} \\
0.2 \mathrm{ml} . \\
2.3 \times 10^{6}\end{array}$} \\
\hline
\end{tabular}


group are related to the mean area of the reaction. The reactions were divided by area into five different classes and the number of individuals in each class was found not to be affected by the degree of concordance.

TABLE III.-Concordance of Reaction with ABO Blood Group and Sex

\begin{tabular}{|c|c|c|c|c|c|c|c|c|}
\hline \multirow{3}{*}{ Donors } & \multicolumn{2}{|c|}{ Concordance With } & \multicolumn{6}{|c|}{ Reaction } \\
\hline & \multirow{2}{*}{$\begin{array}{c}\text { ABO } \\
\text { Blood } \\
\text { Group }\end{array}$} & \multirow[b]{2}{*}{ Sex } & \multicolumn{3}{|c|}{ First } & \multicolumn{3}{|c|}{ Second } \\
\hline & & & Present & Absent & $\begin{array}{l}\text { Mean } \\
\text { Area } \\
\end{array}$ & Present & Absent & $\begin{array}{c}\text { Mean } \\
\text { Area }\end{array}$ \\
\hline $\begin{array}{ll}\text { Ao } & . \\
\text { AO } & \because \\
\text { Total } & \because\end{array}$ & + & + & $\begin{array}{r}9 \\
8 \\
17\end{array}$ & $\begin{array}{l}1 \\
2 \\
3\end{array}$ & $\begin{array}{l}89 \cdot 3 \\
31 \cdot 1 \\
60 \cdot 2\end{array}$ & $\begin{array}{r}8 \\
7 \\
15\end{array}$ & $\begin{array}{l}2 \\
3 \\
5\end{array}$ & $\begin{array}{l}53 \cdot 6 \\
14.2 \\
43.9\end{array}$ \\
\hline $\begin{array}{ll}\text { Aot }^{*} & \because . \\
\text { Aotal } & \because\end{array}$ & + & $\bar{z}$ & $\begin{array}{r}8 \\
7 \\
15\end{array}$ & $\begin{array}{l}2 \\
3 \\
5\end{array}$ & $\begin{array}{l}38 \cdot 6 \\
62 \cdot 0 \\
50.3\end{array}$ & $\begin{array}{r}8 \\
6 \\
14\end{array}$ & $\begin{array}{l}2 \\
4 \\
6\end{array}$ & $\begin{array}{l}11 \cdot 4 \\
24.4 \\
32.95\end{array}$ \\
\hline $\begin{array}{l}\text { Bô } \\
\text { Bo } \\
\text { Total }\end{array}$ & $\overline{-}$ & + & $\begin{array}{r}6 \\
5 \\
11\end{array}$ & $\begin{array}{l}4 \\
5 \\
9\end{array}$ & $\begin{array}{l}42 \cdot 6 \\
13 \cdot 6 \\
28 \cdot 1\end{array}$ & $\begin{array}{r}7 \\
7 \\
14\end{array}$ & $\begin{array}{l}3 \\
3 \\
6\end{array}$ & $\begin{array}{l}29 \cdot 1 \\
23 \cdot 3 \\
26 \cdot 2\end{array}$ \\
\hline $\begin{array}{ll}\text { Bo } & . . \\
\text { Bo } & \cdots \\
\text { Total } & \cdots\end{array}$ & $\overline{-}$ & $\overline{-}$ & $\begin{array}{r}7 \\
7 \\
14\end{array}$ & $\begin{array}{l}3 \\
3 \\
6\end{array}$ & $\begin{array}{l}13 \cdot 9 \\
14 \cdot 3 \\
14 \cdot 1\end{array}$ & $\begin{array}{r}4 \\
7 \\
11\end{array}$ & $\begin{array}{l}6 \\
3 \\
9\end{array}$ & $\begin{array}{l}18 \cdot 2 \\
42 \cdot 3 \\
30 \cdot 2\end{array}$ \\
\hline
\end{tabular}

+ indicates similarity. - indicates dissimilarity.

From Table IV it will be seen there were a surprisingly large number of negative first reactions and also of negative second reactions. One female volunteer was negative for all four of the primary and all four of the secondary reactions, and did not react when a repeat injection of the same cells was given after one month. No evidence of a circulating factor toxic to the lymphocytes was found on in vitro tests. It is unlikely that loss of viability of lymphocytes was an important cause of negative reactions since the same sample of lymphocytes produced positive and negative first

\begin{tabular}{|c|c|c|}
\hline \multicolumn{2}{|c|}{ Reaction } & \multirow{2}{*}{ No. } \\
\hline First & Second & \\
\hline $\begin{array}{l}\text { Present } \\
\text { Present } \\
\text { Absent } \\
\text { Absent }\end{array}$ & $\begin{array}{l}\text { Present } \\
\text { Absent } \\
\text { Present } \\
\text { Absent }\end{array}$ & $\begin{array}{l}45 \\
9 \\
12 \\
14\end{array}$ \\
\hline
\end{tabular}

reactions in different people. The high proportion of negative reactors appears to be usual, for a repeat experiment using different blood donors as volunteers (on this occasion unrelated for $A B O$ blood group and sex) gave a similar distribution of negative and positive first and second reactions.

\section{Discussion}

If concentrated lymphocytes are considered as analogous to a tissue graft, the first reaction in the present experiments could be regarded as a graft-versus-host and the second as a hostversus-graft reaction.

Interpretation of the second reaction is difficult because each volunteer received four injections of different homologous lymphocytes. Had any of these possessed antigenic material in common the second response to this stimulus might have been more pronounced. However, the areas of the second reaction were as variable in size as the first, and the two did not correlate.
The complete absence of a first response in some cases suggests that the cell recipient has important histocompatibility antigens in common with the cell donor, but as homografts are almost invariably rejected it seems improbable that tissue from so many negative reactors to their cell donors would have been accepted. It is clear that the lymphocyte-test phenomena are only part of the total picture, and it is to be expected that a homograft from a cell recipient with a negative first reaction to the lymphocyte donor would still be rejected.

In this experiment it was considered unethical to attempt skin grafts because the volunteers were blood donors, but this should be done if the real usefulness of the lymphocyte-transfer test is to be put to the trial. Only tissue transplants will show whether the test does give an indication of graft acceptability, but our results do not suggest that it is a sensitive indicator. However, tissue from donors selected by this test may have a better chance of being accepted, especially if aided by immunosuppressive therapy in the recipient. It will be interesting to see how the size of the weals in our experiments correlates with the leucocyte typing of the recipients and donors. This work is at present in progress and will be the subject of a further paper.

\section{Summary}

An evaluation of the influence of $\mathrm{ABO}$ blood group and sex on the normal lymphocyte-transfer test is presented, together with a new technique for recording results. First and second reactions were observed, and a high proportion of negative reactions recorded. The results show that blood group and sex have no influence on the reactions obtained. The test may indicate degrees of incompatibility between graft recipients and members of a tissue-donor panel. We wish to emphasize the possible danger of intradermal injections of dextran.

ADDENDUM.-It is conceivable that blood-group iso-antibodies could combine with corresponding antigens on donor lymphocytes and lead to some inhibition of the first reaction. This possibility is at present under investigation.

We wish first to thank the Liverpool blood donors for volunteering and attending for injections. We are grateful to Dr. C. A. Clarke for suggesting the experiment; to Professor P. M. Sheppard for his help in its design; to Dr. J. C. Woodrow for his assistance in the preparation of the manuscript ; to Dr. D. Lehane and Dr. M. McCarthy for providing facilities for the tests; and to Dr. H. J. Goldsmith and Dr. P. Jones for their help in the pilot experiments. Our thanks are also due to Dr. R. Augustin for carrying out the double-layer leucocyte-agglutination test, and to Dr. L. Brent and Professor P. B. Medawar for testing the dextran solution and for helpful comments on the manuscript. We are also grateful to Mr. W. T. A. Donohoe for the serology, and to Mrs. M. Cooper for secretarial assistance.

\section{REFERENCES}

Brent, L., and Medawar, P. B. (1963). Brit. med. F., 2, 269.

Bridges, J. M., Nelson, S. D., and McGeown, Mary G. (1964). Lancet, 1,581 .

Goldsmith, K. L. G. (1964). Ibid., 1, 614.

Gray, J. G., and Russell, P. S. (1963). Ibid., 2, 863.

Kabat, E. A., Turino, G. M., Tarrow, A. B., and Maurer, P. H. (1957). F. clin. Invest., 36, 1160 .

Ridges, A. P., and Augustin, R. (1964). Nature (Lond.), 202, 667. 